\title{
Entrepreneur as a Career Choice: Interrelationship between Risk Taking, Competitive Aggressiveness, Proactiveness, Innovativeness, and Autonomy
}

\author{
${ }^{1}$ Bustanul Arifin Noer, ${ }^{2}$ Muhammad Syafi' ie Idrus, ${ }^{3}$ Djumilah Hadiwijoyo, \\ ${ }^{4}$ Budisantoso Wirjodirdjo \\ ${ }^{1}$ Department of Industrial Engineering - Institut Teknologi Sepuluh Nopember (ITS), Surabaya, Indonesia \\ ${ }^{2}$ Professor, Department of Management - Faculty of Economic and Business - Universitas Brawijaya, Malang, \\ Indonesia \\ ${ }^{3}$ Professor Emeritus, Department of Management - Faculty of Economic and Business - Universitas Brawijaya, \\ Malang, Indonesia \\ ${ }^{4}$ Professor, Department of Industrial Engineering - Institut Teknologi Sepuluh Nopember (ITS), Surabaya, \\ Indonesia
}

\begin{abstract}
It is commonly believed that entrepreneurs are one of the main pillars of nation economic growth or development due to their ability to create jobs. Entrepreneur as a career choice has known since ancient time along with career as non-entrepreneur. Research on entrepreneurship is increasingly performed in last period along with the decrease in employment opportunities. This research aims to analyze the personal characteristics that influence university graduates to choose entrepreneur as their career option. Based on previous research, five factors were identified, i.e: risk taking, competitive aggressiveness, proactiveness, innovativeness, and autonomy. Data were collected from 76 respondents. Data were then analyzed using descriptive analysis, cross tabulation, confirmatory factor analysis, discriminant analysis, and logistic regression to test how those factors relate to career choice as an entrepreneur. The analysis shows that only three factors significantly influenced the choice of entrepreneur as career choice, i.e. proactiveness, risk taking, and competitive aggressiveness. While the other two factors - innovativeness and autonomy - were found to be basic characteristics required for both an entrepreneur and non-entrepreneur.
\end{abstract}

Key words: career choice, entrepreneur, non-entrepreneur, risk taking, competitive aggressiveness, proactiveness, innovativeness, autonomy

Submitted Date 26 June 2013

Accepted Date: 01 July 2013

\section{Introduction}

It is commonly believed that entrepreneurs are one of the main pillars of nation economic growth or development due to their ability to create jobs. However, growth in the number of entrepreneurs, particularly Indonesia is very low. Research on entrepreneurship (things related to the figure of an entrepreneur) is increasingly performed in the last period along with the decrease of employment opportunities.

In regard to universities' graduates, there is only very low number of graduates who choose a career as an entrepreneur. Entrepreneur as a career choice has been kown since ancient times along with a career as nonentrepreneur. Noer (2010a and 2010b) found that from sample which total was 68 of Industrial Engineering alumnae from ITS (Institut Teknologi Sepuluh Nopember) Surabaya - Indonesia, only 11,6\% who choose a career as entrepreneur. Tremblay, Wils, and Proulx (2002) found majority of graduate engineers in Canada tend to choose managerial career rather than entrepreneurial, technical, hybrid, or project. DeMartino and Barbato (2003) only found 16,2\% female entrepeneur and 11,5\% male entrepreneur from sample of 1,763 MBA (Master of Business Administration) alumnae from 10 universities in the United States of America.

Burke, FitzRoy, and Nolan (2003) coined the term of self-employment or wage-employment and entrepreneur. Hirsky and Tuunanen (undated) coined the term entrepreneur and non-entrepreneur. Verheul, Wennekers, Audrestch, and Thurik (2001) divide the 3 groups of entrepreneur with reference to the entrepreneurial or managerial ability and whether they are self-employed or employees, as shown in Figure 1. 


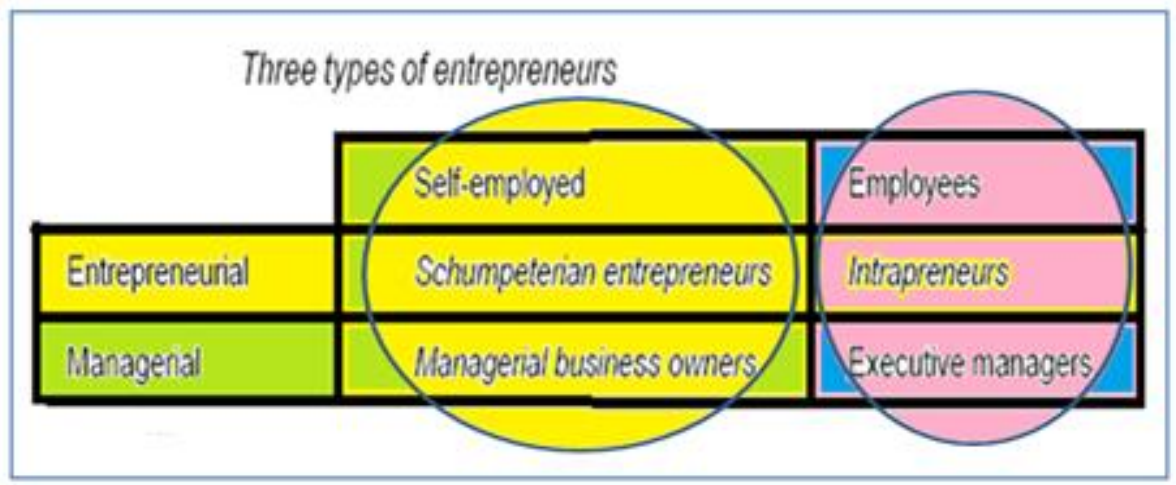

Figure 1 Three Types of Entrepreneur

Source: Verheul, Wennekers, Audrestch, dan Thurik (2001) and has modified

Those who have entrepreneurial skills and self-employed is called Schupeterian entrepreneur or simply as an entrepreneur. Ravasi and Turati (2005) state that entrepreneurs are the main key holder for the world economic growth. Intrapreneur is a term for those who have entrepreneurial skills, but still works for another person or party as an employee.

The university student is a unique and potential figure to become an entrepreneur, if indeed it is the choice of their careers after the graduation. Similarly, the alumnae of the university is a figure that could potentially lead to be more successful entrepreneur, if indeed it is the choice of their career. Lühtje and Franke (undated) have demonstrated the existence of entrepreneurial intensity and the creation of entrepreneur that keeps on increasing among engineering students at MIT (Massachusetts Institute of Technology), United States of America.

The alumnae of Industrial Engineering ITS Surabaya (and alumnae from other universities) could have choosen a career as an entrepreneur or non-entrepreneur depends on their invidual choice. Entrepreneur or nonentrepreneur still requires entrepreneurial and managerial skills with various level in everyone. Department of Industrial Engineering of ITS Surabaya already perform 3 levels of education (bachelor degree since 1985, master degree since 1994, and doctoral degree since 2009).

The issue that remains to be answered is why not many alumnae of Industrial Engineering ITS Surabaya choose a career as an entrepreneur. Are there variables that can explain the difference between those who choose an entrepreneur with a non-entrepreneur of 5 major variables (risk taking, competitive aggressiveness, proactiveness, innovativeness, and autonomy)? The purpose of this research is to analyze interrelationship among those 5 variables in Industrial Engineering alumnae from ITS Surabaya to their career choice..

\section{Literature Review}

Lyon, Lumpkin, and Dess (2000) raise 5 dimensions of entrepreneurial orientation, namely: risk taking, competitive aggressiveness, proactiveness, innovativeness, and autonomy. Entrepreneurial orientation is different from entrepreneurship. Entrepreneurship is more geared to the new entrants in the business, while entrepreneurial orientation has been related to the process of how entrepreneurship is running that icludes the methods, practices, and decision making styles for entrepreneurial act. The concept of entrepreneurial orientation also stated by Aloulou (2002), Sembhi (2002), Lumpkin and Dess (2001), Wiklund and Sheperd (2005), Brown and Davidsson (undated), also Hean, Thi, and Hwei (2007). Entreprenurial orientation is often paired with the term of corporate entrepreneurship or intrapreneurship [Antoncic dan Hisrich (undated); Hitt, Ireland, and Hoskisson (2000); Kuratko and Hornsby (undated); Srivastava and Lee (2005); Gupta, McMillan, and Surie (2004)].

Entrepreneurship is all matters relating to the attitudes, actions, and processes undertaken by entrepreneurs in pioneering, managing, and developing their businesses (Bruyat and Julien, 2000). Kantis, Masahiko, and Masahiko (2002) had defined entrepreneurship as the capacity to establish and develop the new business. Pfeifer (2003) provides a definition of entrepreneurship as the act of value creation through the realization of a business opportunity with risk-taking and the use of human capital, social, financial, and physical. Entrepreneurial activity within the company is shown in a variety of activities, along with risk-taking, competitive aggressiveness, proactiveness, innovativeness, and autonomy by all personnel in the company (Lyon, Lumpkin, and Dess, 2000).

Every one can become an entrepreneur, either sooner or later, if they have a strong belief and desire in that direction (Odgers, undated). For that purpose, there is necessity of knowledges, skills, and attitutdes as entrepreneurs themselves. Being an entrepreneur can be done at any time, including after retirement. Efforts that 
Entrepreneur as a Career Choice: Interrelationship Between Risk Taking, Competitive Aggressiveness,

being builts was usually start from the small one which then continue to be great. Sarasvathy (2002) argue that things that must be done by entrepreneur is realizing something into a real business that grow continuously.

Chandra (2005) support the notion that every one has the potential to be an entrepreneur with the requirements and steps which are not easy. Entrepreneurs are those that can combine two important things in buisnes, namely (1) strategic thinking and (2) focus of the action. Nasution, Noer, and Suef (2001 and 2006) in a practical and applicable way also describes how a framework to build an entrepreneurial spirit and attitude to become a technopreneur. Ubacharan et al (undated) states that research in the field of entrepreneurship still wide open to explore more deeply, whether for its theoritical aspects, processes, organization types, the results, as well as the external environment. Sembhi (2002) states that entrepreneurship be the part of entrepreneurial orientation (also known as intrapreneurship or corporate-entrepreneurship) by adding the decision making activities, processes, and practices. Hitt, Ireland, and Hoskisson (2000) states that corporate-entreprenurship much broder in scope than entrepreneurship.

\section{Relationship Between Risk Taking, Competitive Aggressiveness, Proactiveness, Innovativeness, and Autonomy Against Career Choice}

Risk taking is the process of decision making and actions without sufficient kowledge of the likely outcome. There are 3 types of risk taking that must be faced by the company and its executives, namely (1) business risk taking, in the form of risk related with entry the new market prior testing or using untested technology, (2) financial risk taking, in the form of expenses or large loan without adequate knowledge of the chances of success, and (3) personnel risk taking, in the form of executives attitude in the determination of strategic action that might influence their subsequent career progression [Koiranen, Hyrzky, and Tunnanen (1997); Carland, Carland, and Stewart (1999)].

Palich and Bagby (1995) argues that there is no real difference betwen entrepreneur and nonentrepreneur in terms of risk taking. Opinions differ with the findings of Simon, Houghton, and Aquino (1999) who actually said that entrepreneurs are those who have a low perception of risk, making them more easier to make dicision to run a business. The entrepreneur has a higher score in terms of risk taking compared to nonentrepreneur are supported by other experts [Stewart, Watson, Carland, and Carland (1999); Envick and Langford (2000); Blackman, Hurd, and Timo (undated); Soo and Poh (2004); Mullins and Forlani (2005); Wiklund and Sheperd (2005); Ravasi and Turati (2005)].

Competitive aggressiveness is a responsive attitude towards any threats as a form of resistence and attemps to win the competition. Stewart, Watson, Carland, and Carland (1999) use the term of pursuit achievement to show competitive aggressiveness as one of several main characteristic of an entrepreneur. The entrepreneur has a higher score in term of competitive aggressiveness compared with non-entrepreneur are supported by other experts [Blackman, Hurd, and Timo (undated); Lumpkin and Dess (2001); Leiblein and Reuer (2004)].

Proactiveness is characterized by readiness to introduce new products or services in the arena of competition as well as having the anticipation of future demand. Baron (1998) suggest that entreprenurs are those who have higher score in term of proactiveness than non-entrepreneurs as proposed by other experts [Lumpkin and Dess (2001); Ardichvili, Cordoza, and Ray (2003); Wiklund and Sheperd (2005)].

Innovativeness is a desire to provide support for creativity and experimentation in introducing new products. Creativity is more referes to creating many ideas, while innovation is the implementation of the idea that become product with value. Creative people can be characterized by the following: (1) able to control their emotions, (2) has empathy, (3) flexible in thinking/acting and interested in creative activities, and (4) forwardlooking and belief in their own idea (Antonites, 2003).

Palich and Bagby (1995) states that entrepreneurs are those who see more on an opportunity rather than a threat, so they are more creative in setting the pace and get the right answeres than nonentrepreneurs. Creativity and innovation of entrepreneurs is higher than non-entrepreneurs [Baron (1998); Stewart, Watson, Carland, and Carland (1999); Blackman, Hurd, and Timo (undated); Soo and Poh (2004); Leiblein and Reuer (2004); Wiklund and Sheperd (2005); Ravasi and Turati (2005)]. In contrast, the other opinion says that there is no siginificant defference in terms of innovativeness between nascent entrepreneur and non-entrepreneur (Carter, Gartner, Shaver, and Gatewood; 2003).

Autonomy is a requirement that must be owned to run a business even without the support of any party. Autonomy is the main characteristic of the successful entrepreneur. Palich and Bagby (1995) states that entrepreneur has higher score in term of autonomy rather than non-entrepreneur. Entrepreneurs are those who are more demanding and demonstrates commitment rather than making consideration about his/herself as an independent person in thought and action [Baron (1998); Envick and Langford (2000); Lyon, Lumpkin, and Dess (2000); Blackman, Hurd, and Timo (undated); Soo and Poh (2004)]. However, there is one article that said there was no significant difference in term of autonomy between nascent entrepreneur and non-entrepreneur (Carter, Gartner, Shaver, and Gatewood; 2003). 


\section{Research Framework}

Theoretical framework for this research is made based on the results of the existing literature. Starting from the concept of entrepreneurial orientation with 5 main dimensions, then revealed how the existing theoretical and developed one in this research.

\section{Construct and Indicator Variables}

Construct of risk taking consists of 10 indicators (manifest variables), namely: (X1.1) willing to do the hard work when necessary, (X1.2) willing to do a job even without the help of others, and so on until (X1.10) ready to do what is wrong. Construct of competitive aggressiveness that paire well with achievement orientation consists of 11 indicators, namely: (X2.1) trying to perform better even without a financial incentive bonus, (X2.2) appreciate the work performance more than the exchange of money, and so on until (X2.11) aggressively following the company's achievement and beat the competitors. Construct of proactiveness consists of 9 indicators, namely: (X3.1) plan many things even though sometimes fail, (X3.2) have a definite career goals in the workplace, and so on until (X3.9) tried to seize every opportunity for a better career in the future [processed further from: Hitt, Ireland, and Hoskisson (2000); Noer and Wirjodirdjo (2007)].

Construct of innovativeness consists of $\mathbf{1 5}$ indicators, namely: (X4.1) has good imagination and idea, (X4.2) likes to try new ways of doing things, and so on until (X4.15) has a high commitment to do the job/task. Construct of autonomy consists of $\mathbf{1 3}$ indicators, namely: (X5.1) bold and optimistic in decision making and its implementation, (X5.2) can perform well even without the help of the another, and so on until (X5.13) able to complete the task or order in accordance with the schedule set forth [processed further from: Hitt, Ireland, and Hoskisson (2000); Soo and Poh (2004); Noer and Wirjodirdjo (2007)].

\section{Hypothesis}

1. Hypothesis $1\left(\mathrm{H}_{1}\right)=$ Risk taking of Industrial Engineering alumnae from ITS Surabaya has an influence on their career choice. Those with a higher score in risk-taking tend to choose a career as an entrepreneur rather than non-entrepreneur.

2. Hypothesis $2\left(\mathrm{H}_{2}\right)=$ Competitive aggressiveness of Industrial Engineering alumnae from ITS Surabaya has an influence on their career choice. Entrepreneur's career choice is mostly done by those who have higher score in competitive aggressivenes rather than non-entrepreneur.

3. Hypothesis $3\left(\mathrm{H}_{3}\right)=$ Proactiveness of Industrial Engineering alumnae from ITS Surabaya has an influence on their career choice. Entrpreneur's career choice is mostly done by those who have higher score in proactiveness rather than non-entrepreneur.

4. Hypothesis $4\left(\mathrm{H}_{4}\right)=$ Innovativeness of Industrial Engineering alumnae from ITS Surabaya has an influence on their career choice. Entrpreneur's career choice is mostly done by those who have higher score in innovativeness rather than non-entrepreneur.

5. Hipotesis $5\left(\mathrm{H}_{5}\right)=$ Autonomy of Industrial Engineering alumnae from ITS Surabaya has an influence on their career choice. Entrpreneur's career choice is mostly done by those who have higher score in autonomy rather than non-entrepreneur.

\section{Methodology}

Tere are 6 stages required, namely: research design, research sample, measurement instrument, data collection, data processing, and data analysis. This research is an exploratory and explanatory studies about how Industrial Engineering alumnae from ITS Surabaya choose their career associated with their risk taking, competitive agressiveness, proactiveness, innovativeness, and autonomy.

\section{Population and Research Sample}

The population is alumnae of Industrial Engineering of ITS Surabaya, both bachelor and master degree. The total of Industrial Engineering graduation until September 2010 period was 1,614 undergraduate and 416 master's, bringing the total number of Industrial Enggineering alumnae from ITS Surabaya to 2,030 graduates. The respondents are located in Surabaya and sorrounding area as well as via email that can reach a wider area. Time of data collection was conducted in January - February 2010 and March 2011.

\section{Research Instruments}

Types of data used is primary data, except for data on the number of alumnae that obtained from student affairs of Industrial Engineering Department of ITS Surabaya. Data were collected directly in the two groups of alumnae (S1 for undergraduate or bachelor; S2 for master). Demographic variables of respondent are nominal scale. Likert scales $1-5$ are used for observable variables that refer to risk taking, competitive 
aggressiveness, proactiveness, innovativeness, and autonomy. Career choice variable included in first group which is categorical.

\section{Data Collection and Processing}

Data collection procedure with the following step: contacting representatives of each class of alumnae who live in Surabaya and sorrounding, come and give the questionnaires as well as a way of filling, track the position of alumnae through the alumnae miling list and distributing questionnaires, collecting questionnaier materials, receive and impart comment back to the questionnaire materials, as well as data processing. Stage of data processing carried out after all the data is collected. There 7 steps and processes implemented, namely: data summary, descriptive analyisis, cross tabulation, conformatory factor analysis, discriminant analysis, logistic regression analysis, and hypothesis testing.

\section{Results and Discussions}

The survey resulted 76 responses. Samples of alumnae groups S1 (bachelor) is 61 respondents and from alumnae S2 (master) is 15 respondents. Career choice of Industrial Engineering alumnae from ITS Surabaya for the entire samples was recorded $13.2 \%$ (10 of 76 respondents) as an entrepreneur, and the remaining $86.8 \%$ as non-entrepreneur (managers, excecutives, or employees who work for the other party, all of alumnae $\mathrm{S} 2$ choose their career as non-entrepreneur).

There is a significant association $(\alpha=10 \%)$ between the group of alumnae wtih their career choice. Career choice as an entrepreneur only be done by the alumnae of S1 and no one from the alumnae of S2, while career choice as non-entrepreneur is performed by both group of alumnae (Pearson Chi-Square $=\mathbf{2 . 8 3 2} ; \boldsymbol{p}$ value $=0.092$ ).

\section{Interrelationship Between 5 Main Variables}

Interrelationship between 5 main variables of risk taking, competitive aggressiveness, proactiveness, innovativeness, and autonomy can be seen as in Figure 2. There was enough to confince with the standard loading $>0.60$ except that occured between risk taking and proactiveness wich only worth 0,49 .

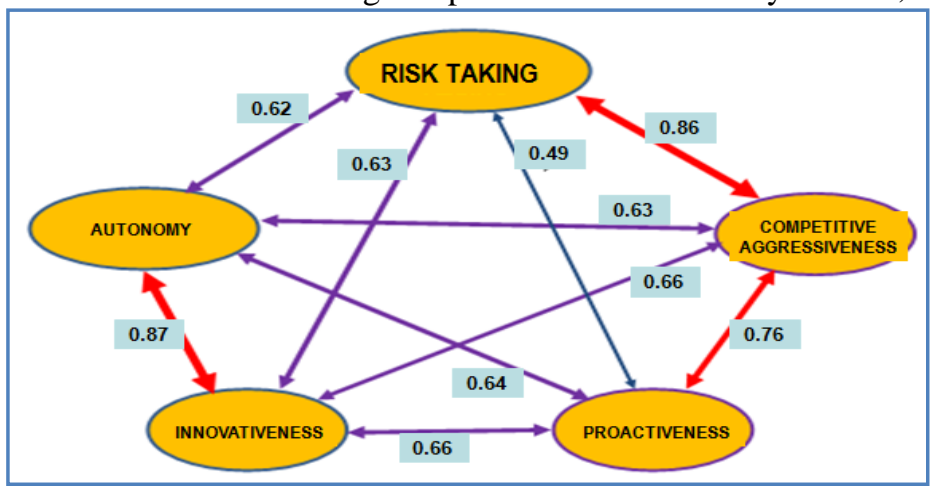

Figure 2. Interrelationship Between 5 Main Variables Source: proceed by-self from print-out

The most powerful interrelationship is between innovativeness and autonomy (0.87) which means that the higher the person's innovativeness so the higher their autonomy, and vice versa. The next strong interrelationship is between risk taking and competitive aggressiveness $(0,86)$ which means that the higher the one's risk taking so the higher their competitive aggressiveness. The other relationship can be seen in Figure 2.

\section{Logistic Regression Analysis Results}

Logistic regression analysis was perform on the aggregation of 5 main variables. The value of $\operatorname{Exp}(\boldsymbol{B})$ note that proactiveness was the most determining variable for one's opportunity to choose a career as an entrepreneur, then followed by risk taking, and then followed by competitive aggressiveness. Career choice as an entrepreneur is determined by the high score on one's proactiveness, risk taking, and competitive aggressiveness. Innovativeness and autonomy are equally needed in any career, whether as an enterpreneur or non-entrepreneur.

The main characteristics of those whose a career as an entrepreneur from the aspect of risk taking is their readiness of making mistakes and their willingness to open a new venture though not necessarily obtain definitive results. The main aspect of competitive aggressivenes that belong to an entrepreneur is their effort to perform better even whitout a financial incentives bonus and their responsiveness to potential threats. The main 
Entrepreneur as a Career Choice: Interrelationship Between Risk Taking, Competitive Aggressiveness,

aspect of proactiveness that belong to an entrepreneur is their effort in introducing new products to the market as well as their readiness to seek a variety of information about a lot of thing to prepare the next step.

The main characteristics of those whose a career as an entrepreneur from the aspect of innovativeness is their ability to realize the idea into something usefull as well as their interest in creative activies. The main aspect of autonomy that belong to an entrepreneur is their strong confidence on the success of a business carried on as well as their ability to work independently in running a business.

\section{Hypothesis Test Results}

Hypothesis $1\left(\mathrm{H}_{1}\right)$ has proved significantly that risk taking influence career choice. Those who show more courage in risk taking would tend choose their career as an entrepreneur rather than non-entrepreneur. This finding refuted Palich dan Bagby (1995), but supports the concept presented by many other experts that entrepreneur has a bolder stance in risk taking rather than non-entrepreneur [Simon, Houghton, and Aquino (1999); Stewart, Watson, Carland, and Carland (1999); Envick and Langford (2000); Blackman, Hurd, and Timo (undated); Soo and Poh (2004); Mullins and Forlani (2005); Wiklund and Sheperd (2005); Ravasi and Turati (2005)].

Hypothesis $2\left(\mathrm{H}_{2}\right)$ has proved significantly that competitive aggressiveness influence career choice. Those who dare to competitive aggressiveness tend to choose their career as an entrepreneur rather than nonentrepreneur. These findings suppport the concept put forward by many other experts that those who choose a career as an entrepreneur has bold stance in competitive aggressiveness greater than those of non-entrepreneur [Stewart, Watson, Carland, and Carland (1999); Blackman, Hurd, and Timo (undated); Lumpkin and Dess (2001); Leiblein and Reueur (2004)].

Hypothesis $3\left(\mathrm{H}_{3}\right)$ proved significantly that proactiveness influence career choice. Those who has more proactiveness tend to choose a career as an entrepreneur rather than non-entrepreneur. These findings support the concept put forward by many other experts that those whos choose a career as an entrepreneur has higher in their proactiveness rather than whose a career as non-entrepreneur [Baron (1998); Lumpkin dan Dess (2001); Ardichvili, Cordoza, dan Ray (2003); Wiklund dan Sheperd (2005)].

Hypothesis $4\left(\mathrm{H}_{4}\right)$ is not proved significantly, which means that innovativeness is not influence career choice. Career choice as an entrepreneur or non-entrepreneur needs innovativeness as well. These findings do not support the concept put forward by many other experts [Palich and Bagby (1995); Baron (1998); Stewart, Watson, Carland, and Carland (1999); Blackman, Hurd, and Timo (undated); Soo and Poh (2004); Leiblein and Reuer (2004); Wiklund and Sheperd (2005); Ravasi and Turati (2005)]. However, this finding supports the results presented by Carter et al (2003) who said that there was no difference between nascent entrepreneur and non-entrepreneur in their innovativeness.

Hypothesis $5\left(\mathrm{H}_{5}\right)$ is not proved significantly, which means that autonomy is not influence the career choice. Career choice as an entrepreneur or non-entrrpreneur both require autonomy as well. These findings do not support the concept put forward by many other experts [Palich and Bagby (1995); Baron (1998); Envick and Langford (2000); Blackman, Hurd, and Timo (undated); Soo and Poh (2004)]. These findings support the results presented by Carter et al (2003) who says that there was no difference between nascent entrepreneur dan nonentrepreneur in their autonomy.

\section{Prediction Model of Entrepreneur Career Options}

From the results of logistic regression analysis formula can be obtained as follows:

$$
\begin{aligned}
& 2.4527(\mathbf{X}) \\
& \text { Description: } \\
& \text { Logit }(\boldsymbol{p})=\text { dependent variable 'Career Choice' }(\mathbf{1}=\text { entrepreneur and } \mathbf{0}=\text { non-entrepreneur }) \\
& \mathbf{X 3}=\text { independent variable 'Proactiveness' - aggregation of } 9 \text { from } 9 \text { manifest variables } \\
& \mathbf{X 1}=\text { independent variable 'Risk Taking' - aggregation of } 5 \text { from } 10 \text { manifest variables } \\
& \mathbf{X} \mathbf{2}=\text { independent variable 'Competitive Aggressiveness' - aggregation of } 10 \text { from } 11 \\
& \text { manifest variables } \\
& \mathbf{X 5}=\text { independent variable 'Autonomy' - aggregation of } 12 \text { from } 13 \text { manifest variables } \\
& \mathbf{X} \mathbf{4}=\text { independent variable 'Innovativeness' - aggregation of } 6 \text { from } 15 \text { manifest } \\
& \text { variables }
\end{aligned}
$$

Prediction model for the choice of career as an entrepreneur from 5 aggregation variables (risk taking, competitive aggressiveness, proactiveness, innovativeness, and autonomy) is affected by $\mathbf{3}$ (three) variables with positive regression coeffcient sequently as follows: proactiveness to face the future, courage in risk taking, and courage for competitive aggressiveness (or spirit of pursuing achievement). 
When inserted the average score for all variables to that formula (proactiveness $=3.96$; risk taking $=$ $3.65 ;$ competitiveness aggressiveness $=4.25 ;$ innovativeness $=4.07 ;$ autonomy $=4.13$ ), then can be obtained $\boldsymbol{p}$ $=\mathbf{0 . 0 8 8 6}$ which means that the chances of a respondent to choose a career as an entrepreneur is $\mathbf{8 . 8 6 \%}$ (small chance). It can used as an answer to the question 'Why does only a small portion of Industrial Engineering alumnae of ITS Surabaya who choose a career as an entrepreneur?' The bigger the average score for the independent variables with positive sign (proactiveness, risk taking, and competitive aggressiveness), the greater the chances for a person to choose a career as an entrepreneur.

\section{Learning Process Recommendations of Introduction to Technopreneurship}

The course of Introduction to Technopreneurship is a mandatory lecture for all students at ITS Surabaya. The faculty advisor is expected to encourage students appreciation to the critical risk taking variables as followed: (X1.9) willing to accept assignments or orders that may be wrong in the process, (X1.10) ready to do what is wrong, (X1.4) willing to open businesses although there is no certain results, and (X1.3) willing to accept challenging assignments or orders as not yet definetely succeded.

The faculty advisor is expected to encourage students appreciation to the critical competitive aggressiveness variables as followed: (X2.10) follow and beat movement of coworkers aggressively, (X2.11) follow and beat competitors achievement aggressively, and (X2.3) responsive to any threat. The faculty advisor is expected to encourage students appreciation to the critical proactiveness variables as followed: (X3.8) attempted to introduce new products to the market, (X3.6) has a mature work plan for each month running, (X3.1) plan a lot of things even though sometimes fail, and (X3.2) have a definite purpose on a career in the workplace.

There is one significant innovativeness variable, namely (X4.3) able to realize the idea into something useful. It is needed to be more convinced for the students that the willingness and ability to realize the idea so that can become something useful as positive attitude that needed if they want to choose a career as an entrepreneur later. The faculty advisor is also expected to encourage students appreciation to the critical autonomy variables as followed: (X5.12) able to work independently in business, (X5.6) can say YES or NO firmly against any decision made, (X5.3) has a strong belief in the success of a business, and (X5.8) able to convince the team for things that are believed to be the true one.

Lectures implementation for the course of Introduction to Technopreneurship at ITS Surabaya by using comination of tutorial, course lecture, business practices, field studies, and business plan for all students is ecxpected to prepare the graduate candidates so that can have an understanding of strong entrepreneurial and managerial skills as well as knowledge about business processes on the basis of science, technology, and design. The course design that have been run to date needs to be develop nad enhanced its effectiveness.

\section{Conclusion}

From the five main variables (risk taking, competitive aggressiveness, proaactiveness, innovativeness, and autonomy), it is found that there are only three significant variables that affecting the career choice of Industrial Engineering alumnae of ITS Surabaya, namely: proactiveness, risk taking, and risk taking. The variable of innovativeness and autonomy did not significantly influence the career choice. Innovativeness and autonomy are equally needed in a career, either as an entrepreneur or non-entrepreneur. From the sample, it was found only $13.2 \%$ who choose a career as an entrereneur. The probability of the respondent to choose a career as an entrepreneur also found only at $8.86 \%$. Suggestions are made for implementing the course of Introduction to Technopreneurship for all under graduate students at ITS Surabaya, Indonesia.

\section{References}

[1] Aloulou, W., Entrepreneurial Orientation Diagnosis in SMEs: Some Conceptual and Methodological Dimensions. Entrepreneurship Research in Europe; Specificities and Prospectives, INPG-ESISAR Valence (France), September 19 - 22 (2002)

[2] Antoncic, B. and Hisrich, R. D. (undated). An Empirical Investigation of Impacts of Corporate Entrepreneurship - Related Contingencies on Organizational Wealth Creation, University of Ljubljana and Case Western Reserve University.

[3] Antonites, A. J., An Action Learning Approach to Entrepreneurial Activity, Innovation, and Opportunity Finding. Faculty of Economic and Management Sciences. University of Pretoria. Johannesburg. South Africa (2003).

[4] Ardichvili, A., Cardoza, R., and Ray, S., A Theory of Entrepreneurial Opportunity Identification and Development, Journal of Business Venturing 18 (2003) $105-123$.

[5] Baron, R. A., Cognitive Mechanisms in Entrepreneurship: Why and When Entrepreneurs Think Differently than Other People, Journal of Business Venturing 13 (1998) 275-294.

[6] Blackman, A., Hurd, T., and Timo, N. (undated), Entrepreneurs: More Honest than We Think, a Preliminary Investigation into the Characteristics and Values of Owner-Managers, Griffith University, Gold Coast. Australia.

[7] Brown, T. E. and Davidsson, P. (undated), Entrepreneurial Orientation versus Entrepreurial Management: Relating Miller/Covin \& Slevin's Conceptualization to Stevenson's. Jönköping International Business School.

[8] Burke, A. E., FitzRoy, F. R., and Nolan, M. A., Self-Employment Wealth and Job Creation: The Roles of Gender, non-Pecuniary Motivation and Entrepreneurial Ability, Small Business Economics 19/3 (2002) 255-270.

[9] Carland, J. C., Carland, J. W., and Stewart, W. H., Risk Taking Propensity: an Attribute of Entrepreneurship?: a Comparative Analysis, Academy of Entrepreneurship Journal 5/2 (1999). 
[10] Carter, N.M., Gartner, W. B., Shaver, K. G., and Gatewood, E. J., The Career Reasons of Nascent Entrepreneurs, Journal of Business Venturing 18 (2003) 13-39.

[11] Chandra, P., Who Wants To Be An Entrepreneur? (Panduan Jitu Menjadi Seorang Entrepreneur). Terjemahan oleh Ardi Gunawan. Edisi Pertama. PT Prestasi Pustakaraya. Jakarta (2005).

[12] DeMartino, R. and Barbato, R., Differences Between Women and Men MBA Entrepreneurs: Exploring Family Flexibility and Wealth Creation as Career Motivators, Journal of Business Venturing 18 (2003) 815-832.

[13] Envick, B. R. and Langford, M., The Five-Factor Model for Personality: Assessing Entrepreneurs and Managers, Academy of Entrepreneurship Journal 6/1 (2000).

[14] Gupta, V., McMillan, I. C., and Surie, G., Entrepreneurial Leadership: Developing and Measuring a Cross-Cultural Construct, Journal of Business Venturing 19 (2004) 241-260.

[15] Hean, T. K., Thi, T. M. N., and Hwei, P. N., The Effects of Entrepreneurial Orientation and Marketing Information on the Performance of SMEs, Journal of Business Venturing 22 (2007) 592-611.

[16] Hitt, M. A., Ireland, R. D., and Hoskisson, R. E., Corporate Entrepreneurship and Innovation. Chapter 13. South-Western College Publishing (2000).

[17] Hyrsky, K. and Tuunanen, M., "Jack of All Trades on Route 66" - Entrepreneurs and Entrepreneurship as Expressed in Metaphors, School of Business and Economics, University of Jyväskylä, Finland (undated).

[18] Kantis,. H., Masahiko, I., and Masahiko, K., Entrepreneurship in Emerging Economic - The Creation and Development of New Firms in Latin America and East Asia. Inter-American Development Bank (2002).

[19] Kuratko, D. F. and Hornsby, J. S., Corporate Entrepreneurship and Middle Managers: a Model for Corporate Entrepreneurial Behavior, The Entrepreneurship Program College of Business, Ball State University. Muncie (undated).

[20] Leiblein, M. J. and Reuer, J. J., Building a Foreign Sales Base; The Role of Capabilities and Alliances for Entrepreneurial Firms, Journal of Business Venturing 19 (2004) 285-307.

[21] Lüthje, C. and Franke, N., The 'Making' of an Entrepreneur: Testing a Model of Entrepreneurial Intent Among Engineering Students at MIT, Technical University of Hamburg (undated).

[22] Lumpkin, G. T. and Dess, G. G., Linking Two Dimensions of Entrepreneurial Orientation to Firm Performance: the Moderating Role of Environment and Industry Life Cycle, Journal of Business Venturing 16 (2001) 429-451.

[23] Lyon, D. W., Lumpkin, G. T., and Dess, G. G., Enhancing Entrepreneurial Orientation Research: Operationalizing and Measuring a Key Strategic Decision Making Process, Journal of Management 26/ 5 (2000) 1055-1085.

[24] Mullins, J. W. and Forlani, D., Missing the Boat or Sinking the Boat: a Study of New Venture Decision Making, Journal of Business Venturing 20 (2005) 47-69.

[25] Nasution, A. H., Noer, B. A., and Suef, M., Membangun Spirit Entrepreneur Muda Indonesia: Suatu Pendekatan Praktis dan Analitis, PT Elex Media Komputindo, Jakarta (2001).

[26] Nasution, A. H., Noer, B. A., and Suef, M., Entrepreneurship: Membangun Spirit Teknopreneur. PT Andi Ofset, Yogyakarta (2006).

[27] Noer, B. A., Pilihan Karier (Entrepreneur vs Bukan-Entrepreneur) Alumni Teknik Industri ITS Surabaya Berdasarkan Aspek ESE (Entrepreneurial Self-Efficacy) Mereka, Makalah Prosiding. Seminar Nasional Teknik Industri, 23 Februari, Program Studi Teknik Industri Universitas Pembangunan Nasional 'Veteran' Jawa Timur, Surabaya (2010a)

[28] Noer, B. A., Pilihan Karier (Entrepreneur vs Bukan-Entrepreneur) Alumni Teknik Industri ITS Surabaya Berdasarkan 5 Dimensi Orientasi Entrepreneurial Mereka, Makalah Prosiding. $2^{\text {nd }}$ National Post Graduate Conference on Business and Management, Program Doktor Ilmu Ekonomi Kekhususan Manajemen Bisnis, Universitas Padjadjaran, 12-13 April, Bandung (2010b).

[29] Noer, B. A. and Wirjodirdjo, B., Pola Asuh Orang Tua yang Membentuk Jiwa Wirausaha Anak: Sebuah Studi pada Mahasiswa Teknik Industri ITS Surabaya. Jurnal Ekonomi dan Manajemen (Journal of Economics and Management) 8/2 (2007).

[30] Odgers, J. F., We Are All - or Soon Will Have to Become - Entrepreneurs, RMIT University, Melbourne, Australia (undated). Accessed in Desember 15, 2005.

[31] Palich, L. E. and Bagby, D. R., Using Cognitive Theory to Explain Entrepreneurial Risk-Taking: Challenging Conventional Wisdom, Journal of Business Venturing 10 (1995) 425-438.

[32] Pfeifer, S., Modification Of Entrepreneurial Behaviour By Cultural Factors In Emerging Economy. ICSB 48th World Conference Advancing, Entrepreneurship and Small Business. 15-18 June 2003 in Belfast (Northern Ireland).

[33] Ravasi, D. and Turati, C., Exploring Entrepreneurial Learning: A Comparative Study of Technology Development Projects, Journal of Business Venturing 20 (2005) 137-164.

[34] Sarasvathy, S. D., Making It Happen - Beyond Theories of the Firm to Theories of Firm Design. Presented at Entrepreneurial Cognition Conference at University of Victoria. July 9 (2002).

[35] Sembhi, R. A., Entrepreneurial Orientation: a Review of Selected Literature, University of Waterloo, Ontario Canada (2002).

[36] Simon, M., Houghton, S. M., and Aquino, K., Cognitive Biases, Risk Perception, and Venture Formation: How Individuals Decide to Start Companies, Journal of Business Venturing 15 (1999) 113-134.

[37] Soo, H. L. and Poh, K. W., An Exploratory Study of Technopreneurial Intentions: A Career Anchor Perspective, Journal of Business Venturing 19 (2004) 7-28.

[38] Srivastava, A. and Lee, H., Predicting Order and Timing of New Product Moves: the Role of Top Management in Corporate Entrepreneurship, Journal of Business Venturing 20 (2005) 459-481.

[39] Stewart, W. H., Watson, W. E., Carland, J. C., and Carland, J. W., A Proclivity for Entrepreneurship; a Comparison of Entrepreneurs, Small Business Owner, and Corporate Managers, Journal of Business Venturing 14 (1998) 189-214.

[40] Tremblay, M., Wils, T., and Proulx, C., Determinants of Career Path Preferences Among Canadian Engineers, Journal of Engineering and Technology Management 19 (2002) 1-23.

[41] Ubacharan, D. et al, The Focus of Entrepreneurial Research: Contextual and Process Issues. Institute for Enterprise and Innovation. Nottingham University Business School. Jubile Campus. Nottingham. England (undated).

[42] Verheul, I., Wennekers, S., Audrestch, D., and Thurik, R., An Eclectic Theory of Entrepreneurship: Policies, Institutions and Culture, Tinbergen Institute Discussion Paper, Universiteit van Amsterdam and Vrije Universiteit Amsterdam (2001).

[43] Wiklund, J. and Sheperd, D., Entrepreneurial Orientation and Business Performance: A Configurational Approach, Journal of Business Venturing 20 (2005) 71-91. 